\title{
Pittsburgh at Yellowstone: Old Faithful and the Pulse of Industrial America
}

\author{
Cecelia Tichi
}

Yellowstone National Park became a tourist "Wonderland" only after the 1870 s, when a mix of writers, photographers, illustrators, publishers, and corporations, notably the Northern Pacific Railroad, repositioned its public identity from hell-on-earth to "a big wholesome wilderness" (Muir, Our National Parks 37). A significant part of that shift to a new geophysical identity involved figuration of the human body, a centuries-long practice in geographic description continued in nineteenth-century American public discourse that invoked the body-geography analogy. In Natural History of Intellect (1893), Ralph Waldo Emerson, echoing Scripture, urged geographical exploration because "[n]ature . . . is bone of our bone, flesh of our flesh, made of us" (165). Other writers exploited bodily terms to describe topographical features and geopolitical entities in the US. Henry David Thoreau had opened his Cape Cod (1865) with an extended trope of Massachusetts as an anatomically configured pugilist ("Cape Cod is the bared and bended arm of Massachusetts" [851]), while in Life on the Mississippi (1883), Mark Twain observed that the river "is always changing its habitat bodily - is always moving bodily sidewise" (40-41). In the latter decades of the century, as Yellowstone and its geyser region became identified as an American "Wonderland," texts supporting the newer identity participated in the kinds of figuration proliferating in contemporary essays and narrative.

In part, the bodily terms in texts on Yellowstone operated as a familiarizing stratagem whereby the distant alien land of rocky mountain ranges, erupting geysers, mud volcanoes, boiling springs, and the like became more conceptually accessible. But attention to the role of figuration of the human body in texts on Yellowstone from the 1870 s to the 1920 s reveals, in addition, the "double discourse of the natural and the technological" (Seltzer 152). This discourse, especially focused on the geyser, Old Faithful, produced an icon of industrial America. To recognize this is 
also to see the basis on which the geyser area became a text on the sociocultural disjunctions of the new industrial order.

Prior to a series of explorations beginning in 1869, the Yellowstone area was known as "Colter's Hell," a tall-tale scene of "burning plains, immense lakes, and boiling springs" (William F. Raynolds, qtd. in Kinsey 45) encountered at first-hand by a few white trappers, hunters, and mountaineers dating back to John Colter's foray in the area in 1807-08, when he split off from the Lewis and Clark expedition and ventured into Yellowstone (Kinsey 45-46). Colter was not alone, for another of the first white male explorers of the region, James Bridger, had called it "a place where hell bubbles up" ("Yellowstone Park" 248).

Such descriptions fit earlier nineteenth-century fables of the far West as "scenes of barronness and desolation," of "the most dismal country" riddled with man-eating grizzlies, of "dismal and horrible mountains," of the "desert," of endless plains "on which not a speck of vegetable matter existed" (Lawson-Peebles 224-25). In order for the Yellowstone area to become credible as a national park and tourist "Wonderland," as it was called by the Helena Daily Herald in 1872, it was necessary that it be assigned a new public identity.

This was achieved, as we shall see, in part by bodily figuration appearing both in travel and expeditionary texts. But the whole process of Yellowstone's reidentification has been documented as a part of the larger post-Civil War project by which the trans-Mississippi West, theretofore understood to be the Great American Desert, now became a pathway to the "Edenic civilization that would occur as Americans entered the region, settled there, exploited its natural resources, and made the West over in their desired image" (Hales 47). In the case of Yellowstone, "Wonderland" replaced the inferno in expeditionary reports by Nathaniel P. Langford (1871) and especially Ferdinand V. Hayden (1872), who extolled the beauty and "magnificent features" of the area (qtd. in Kinsey 83). These were augmented by guidebooks describing Yellowstone's majesty, beauty, enchantment, and by travel writing in the following decades in such middle-class magazines as Harper's, Scribner's, National Geographic, and Atlantic Monthly, whose essays recounted personally inspiring visits and beckoned readers to visit the park for health, adventure, and edification. Throughout one finds a rhetorical strategy using bodily figures to emphasize maternal succor and masculine guardianship.

Yellowstone's new identity was also achieved by visual media, such as the Hayden party's expeditionary photographs of William Henry Jackson. These showed male, shaftlike rock for- 
mations and female valleys, along with canyons and waterfalls that, in compositional terms, "continued the Romantic landscape tradition" (Hales 50). Alan Trachtenberg, discussing the work of Timothy O'Sullivan, another post-Civil War photographer of the West, remarks that such photographs belong to the tradition of landscape art, with landscape referring to a particular genre of academic painting (128).

But painting also played a major role in establishing the new identity of Yellowstone. The painter Thomas Moran, also with the Hayden group, sketched scenes that provided illustrations for essays in Scribner's on "The Wonders of Yellowstone" and for James Richardson's Wonders of the Yellowstone (1872). Probably more importantly, Moran became nationally known for his huge ( 7 by 12 feet) oil painting The Grand Cañon of the Yellowstone (1872), which was publicly exhibited in the US Capitol and instrumental in the creation of the park by an act of Congress signed into law by President Ulysses S. Grant in March 1871 and setting the region aside as "a great national park or pleasure ground for the benefit and enjoyment of the people" (qtd. in Sears 162; see Sears 158-63). In the painting, as in a series of his watercolors, Moran's compositonal exploitation of arches, towers, rocks, and trees, together with his adaptation of the aesthetic principles of John Ruskin and the painterly techniques of Joseph Mallord William Turner in capturing atmospheric effects and color, largely enabled Moran to translate Yellowstone as a landscape of the American sublime, a response codified earlier in the century in relation to America's first icon of nature, Niagara Falls (Kinsey 20-40; McKinsey 30-36, 99). In Moran's painting shafts of rock and tree trunks frame a wide, deep valley from which a central shaft of white mist rises skyward. In bodily terms, one recalls Perry Miller's statement on late-nineteenth-century representations of steam as "the pure white jet that fecundates America," inseminating the "body of the continent" (qtd. in Seltzer 27).

Business, too, was centrally involved in the transformation of Yellowstone from "a place where hell bubbles up" to the new "Wonderland." Scribner's evidently funded the exhibition of Moran's huge canvas in Clinton Hall on New York's Astor Place, just as it published numerous essays on the Yellowstone area illustrated by Moran, including John Muir's. In addition, executives and financiers of the Northern Pacific Railroad understood the advantages of a sublime, enticing Yellowstone for generating income from passengers, freight, and stockholders (Kinsey 64). Subliminally, at least, that shaft of steamy white mist central to Moran's The Grand Cañon of the Yellowstone looked enough like 
locomotive steam to appeal to such groups. The financier Jay Cooke was instrumental in promoting the new image of Yellowstone as exemplum of Western grandeur, and after the collapse of his empire in 1873 the reorganized company continued its public relations campaign on behalf of the area. Joni Louise Kinsey writes of this group of businessmen, artists, and explorers: "Through their collective efforts, [Yellowstone] was transformed from a remote hell on earth into America's wonderland in the public imagination" (58); "By 1890 the demonic perceptions of the place ... were thoroughly transformed. Yellowstone had become, to the eager tourists and the corporations, a wonderland that promised unlimited rewards" (78).

The vocabulary of the human body consistently figured in the transformation of the West and of Yellowstone in particular. One may presuppose that the rock shafts and deep ravines and gorges visually represented in photographs, woodcuts, and oil canvases conveyed a sexualized message of phallic and yonic forms. But an explicit bodily vocabulary can be found in the numerous print texts on Yellowstone. Incongruous as it may seem that texts sustaining the landscape tradition should revert to bodily figuration, the centuries-old practice of delineating geographic traits in bodily terms served the purposes of travel and expeditionary writers, who also followed rhetorical convention from the previous century, such as in one typical late-eighteenthcentury verse on the American continent, "where Oregon foams along the West, / And seeks the fond Pacific's tranquil breast" (Lawson-Peebles 239; see Kolodny).

Breasts, faces, and the other physical features recurring regularly in the production of Yellowstone-as-Wonderland in middle-class American magazines from the 1870s to the 1920s for the most part do so in heterosexually normative terms. Cliffs in the park have "perpendicular faces" ("Washburn" 436). The mountains, like sentinels (presumably male bodies in military posture), "keep watch and ward over this bewilderingly beautiful handiwork of Nature's own" (Armstrong). The object of the sentinels' vigilance is in part the adjectivally female Yellowstone Lake, "a beautiful body of water" (Armstrong) (though elsewhere, in another text, the lake is depicted as shaped like the wounded hand of a German veteran [Dale 6]).

Some writers feminized the park in terms of maternal succor-it mimicked the breast in shape and the production of a sustaining liquid: "The headwaters of the Missouri, Colorado, and Columbia rivers are all suckled here from the same breast of snow," and Lake Yellowstone is "nestled in the bosom of the Rocky Mountains" (Comstock 48; "Washburn" 489). Late- 
nineteenth-century texts also codify Yellowstone National Park as a sentient being expressive of feelings. The "mood" of Yellowstone Lake, for instance, "is ever changing." It "laughs" and then turns "angry" ("Washburn" 490).

Muir, naturalist and leading proponent of the national park system, feminizes the park in terms of "Mother Earth" (Our National Parks 50) but moves anatomically inside the body when he says park visitors are "getting in touch with the nerves of Mother Earth" ("Wild Parks" 16). Muir's image is significant for its anatomical internalization, a direction that various writers followed. In 1893, in The Significance of the Frontier, Frederick Jackson Turner remarked that "civilization in America has followed the arteries made by geology . . . like the steady growth of a complex nervous system for the originally simple, inert continent" (1415). F. W. Hayden explicitly linked the railroad's utilitarian relation to this geological arterial system: "[T] he multitude of rivers that wind like arteries through the country . . . excavate the avenues for our railroads" (qtd. in Hales 69).

This textual mapping of the area in terms of internal organ systems is significant because it enables the production of certain social meanings that devolve from the traits of those organs, including arterial blood flow and cardiac pulse. The arterial rivers conjoin, in cardiovascular terms, with the heart, and, not surprisingly, the 5 April 1873 Harper's Weekly Magazine included an article entitled "The Heart of the Continent: The Hot Springs and Geysers of the Yellow Stone Region" (273-74).

The heart-as-center was, of course, a centuries-old convention but gained a certain agency from the dictum of Ralph Waldo Emerson, whose American scholar is not only "the world's eye" but "the world's heart" ("American Scholar" 73). Cardiac vitality is correlatively located at the center of the Emersonian universe: "[T]he heart at the centre of the universe with every throb hurls the flood of happiness into every artery, vein and veinlet, so that the whole system is inundated with the tides of joy" (Society 30607). In his essay, "The Yellowstone National Park," Muir, a selfproclaimed student and admirer of Emerson, asserted, "The shocks and outbursts of earthquakes, volcanoes, geysers, storms, the pounding of waves, the uprush of sap in plants, each and all tell the orderly love-beats of Nature's heart" (Our National Parks 70).

The health of that heart was measured in a pulse manifest by Old Faithful geyser. In his essay on Yellowstone, Muir describes "a hundred geysers," (54) though Old Faithful was, and is to this day, preeminent. Named by Nathaniel P. Langford and Gustavus C. Doane, who had written of the Yellowstone area 
prior to congressional action, Old Faithful is repeatedly singled out as exemplary.

It is the "most instructive" geyser, wrote Hayden in 1872: "When it is about to make a display, very little preliminary warning is given. There is simply a rush of steam for a moment, and then a column of water shoots up vertically into the air, and by a succession of impulses is apparently held steadily up for the space of fifteen minutes" ("Hot Springs" 175). In 1878, Joseph Le Conte identified the trait-punctual regularity - for which Old Faithful is best known. "'Old Faithful,' he wrote, "[is] so called from the frequency and regularity of its eruptions, throws up a column six feet in diameter to the height of 100 to 150 feet regularly every hour, and plays each time fifteen minutes" (412; emphasis added). Numerous texts from the 1870s cite the unvarying regularity of Old Faithful, always in terms of approval and admiration: It is "the only reliable geyser in the park. You can always bet on seeing him every sixty-five minutes" (Francis 34); there has been no "appreciable difference in its eruptions . . . for over thirty years.... It always displays the same graceful, slender column" (Hague, "The Yellowstone" 523); it is "the geyser of the park" (Weed, "Geysers" 294); Old Faithful sets "a noble example to his followers" and is as punctual as "a tall, oldfashioned clock" (Rollins 886); it is a "perfect" geyser (Hague, "The Yellowstone" 517); "a model geyser" (Henderson 164); "Old Faithful is a friend to every tourist. ... With the regularity of a clock, he pours out his soul toward heaven every sixty minutes and then sinks back to regain new strength" (King 597).

The very name-Old Faithful - connotes the cherished, familiar, and dear. The geyser becomes an object of affection because of its very predictability, its punctuality. The hotel beside it would be named the Old Faithful Inn, as if hospitality itself were linked to the geyser, as if it performed intentionally for the visitors who had endured the inconvenience of travel in order to experience what John Sears has called the "sacred places," the sacralized tourist sublime associated throughout the century with such sites as Niagara Falls, Kentucky's Mammoth Cave, Yosemite's sequoias. More than one writer said the road traveled to the geysers was "dull, dusty, glaring, and disappointing" (Rollins 872), but if Old Faithful failed to meet expectations, no one but Rudyard Kipling said so in print. This cherished, sacred Old Faithful is clearly central to Emerson's and Muir's idea of the organic, benevolent heart of the natural world.

Yet texts from the 1870s to the 1920s indicate that the sociocultural definition of Old Faithful changed radically from the version embraced by Emerson and Muir. Pulse itself becomes a 
crucial term in this change. Numerous commentators characterized geyser eruptions as pulsations. "The geyser," said one writer in 1890 , "is a pool of limpid, green water whose surface rises and falls in rhythmic pulsations... [A]t every pulsation, thick white clouds of steam came rolling out" (Weed, "Geysers" 291). A group in 1882 observed "nine successive pulsations" of the Grand (Francis 35). Many of the "springs ... rise and fall every second or two ... with each pulsation, [by] . . . steady impulses, ... regular pulsations" ("Washburn" 437; Hayden, "Hot Springs" 163, 174).

The pulse in these statements reverts to the arterial pulse, which in medical history is both mechanistic and organic. Texts such as Muir's ally the geysers' rhythms with those of waterfalls, storms, and avalanches, and thus position them with the rhythms of nature (Our National Parks 54). The many references to the steady, regular, clocklike pulsations and eruptions like those above derive from a mechanistic model. With regard to Old Faithful, the relation of the organic to the mechanic is neither a binary division nor an antithesis but a conjunction. The geyser operates as nature's own clockworks.

The regularity of Old Faithful's pulse had a crucial connection to the medical history that linked the body to the clock. Since the early eighteenth century the arterial pulse had been measured by the clock, when Sir John Floyer published The Physician's Pulse Watch (1707), an account of his invention of a mechanical watch with a second hand subsequently standard in time pieces. The sixty-second minute thus became the standard for pulse measurement. Floyer measured patients with "exceeding and deficient pulses" (qtd. in Clendening 12), and these he worked to reregulate. Those that beat too fast or too slowly, according to the measurement of the pulse watch, were treated with medical regimens involving heat and cold. Life consists, Floyer theorized, "in the Circulation of blood, and that running too fast or slow, produces most of our Diseases" (qtd. in Clendening 573-74). The healthy body was that whose pulse throbbed in synchrony with the measurement of the pulse watch.

By the late nineteenth and early twentieth centuries, medical experts agreed that "changes of the pulse are important" (Barwell 89) and recognized a normative range of healthy pulsations even as they named irregularities or arrhythmias, separated the arterial from the venal and hepatic pulses, and devised new instruments for measurement such as the sphygmograph, which showed the pulse is a series of curves (Osler, Principles 650-651). As one specialist wrote in 1902, "The rate of the pulse is the most simple of all signs" and "variations in rhythm are usually readily 
recognized," though "the timing of the various events in a cardiac revolution ... can only be acquired by careful practice ... with the radial pulse as a standard" (Mackenzie 6, viii).

Old Faithful, as we have seen, was celebrated for its hourly pulse measured radially. It met the standard of the sixty-second minute encapsulated within the sixty-minute hour. Its health was proven by its very regularity over decades.

Yet the pulse regularity of Old Faithful involved more than the apparent synchrony of nature with human horology. Muir tries to adhere to the organic model of the Emersonian "heart at the centre of the universe with every throb hurl[ing] the flood of happiness into every artery, vein and veinlet," but other writers, even Muir himself, were responding to a new model of the body as machine. In fact, the repositioning of Yellowstone as the US "Wonderland" included the technologizing of the body and of the material environment. For the post-Civil War decades not only redefined the American West but witnessed the transformation of the Northeast and Midwest into industrial centers. This process, too, is important to the specific ways in which bodily identity produced Old Faithful as an icon of industrial America.

The industrializing American scene is acknowledged in Muir's "Yellowstone National Park," despite the preponderance of pastoral and domestic terms, as though Yellowstone were a designed park, like Frederick Law Olmstead's Central Park or Boston's Fenway or Philadelphia's Fairmount parks. Muir's terms are organic; the very mineral formations are turned into flowers $(47,38)$. Abruptly, however, Muir invokes a radically different environment as he describes the geyser basin. It is as if "a fierce furnace fire were burning beneath each" geyser, "hissing, throbbing, booming," writes Muir. "Looking down over the forests as you approach [the geysers]," he adds, "you see a multitude of white columns, broad reeking masses, and irregular jets and puffs of misty vapor ... entangled like smoke, ... suggesting the factories of some busy town" (Our National Parks 43).

The factories of some busy town-so the "fierce furnace," the noises of hissing, throbbing, and booming after all recall the industrial landscape thousands of miles east of Yellowstone, which, ironically, is the very landscape preserved in its natural splendor from the encroachment of industrialism. The sublime Yellowstone of William Henry Jackson's photographs, of Thomas Moran's huge painting, of the railroad guidebooks and flyers, for that matter of Muir's own crafting, suddenly is challenged by an apparently incongruous, even antithetical, overt image of industrial America.

Comparing the geyser area to "the factories of some busy 
town," Muir's diction collapses the boundaries between the two worlds of nature's "Wonderland" and technological industrialism. The writer whose name had become synonymous with naturalism and conservation, with appreciation of wilderness qua wilderness, who speaks of mineral formations as bouquets of flowers, who writes that the geyser visitors "look on, awe-stricken and silent, in devout, worshipful wonder" seems inadvertently to reveal a major disjunction in consciousness (Our National Parks $53,54)$. The geysers look like a factory, and the most visited site in Yellowstone National Park turns out to be Pittsburgh.

Others, in fact, explicitly named the city identified with steel and coke magnates Andrew Carnegie and Henry Clay Frick in their descriptions of Old Faithful. The "rising smoke and vapor" reminded one writer "of the city of Pittsburgh" (Koch 503), and another observed that "a view of the city of Pittsburg [sic] from a high point would convey some idea of the appearance of this valley [of geysers and hot springs], except that in the former case the dense black smoke arises in hundreds of columns, instead of the pure white feathery clouds of steam" (Hayden, "Hot Springs" 173). In 1880 S. Wier Mitchell, the physician known for his immobilizing "rest cure" for disordered women, described the area of "mud volcanoes" as comparable to "the exhaust of a steam-engine, and near it from the earth come the rattle and crash and buzz and whirring of a cotton-mill" (701). Significantly, it was another nature writer, John Burroughs, who compared the geyser area to an industrial site when he wrote in 1907 that "as one nears the geyser region, he gets the impression from the columns of steam ... that he is approaching an industrial centre" (63).

In part, such comments are utilitarian, measuring wastefulness against a norm of efficient usage. The geysers emit steam "in extravagant ... prodigality. . . . Steam enough is wasted here to run all the Western railways" ("Editor's Study" 320). A writer in The Nation observed that enough geyser water shot into the air "to run all the factories of Pennsylvania for a week" ("Yellowstone" 249). Burroughs "disliked to see so much good steam and hot water going to waste" because "whole towns might be warmed by them, and big wheels made to go round" (64).

Technological analogies providing easily accessible lessons to the reading public also show the extent of middle-class familiarity with mechanistic thinking, as when a geologist in 1898 explained that some geysers "have been formed by explosion, like the bursting of a boiler" (Tarr 1575), or when steam vents are said to "keep up a constant pulsating noise like a high-pressure engine on a river steamboat" (Hayden, "Hot Springs" 164), or 
when geysers are termed "natural steam-engines" (Weed, "Geysers" 299), their vapor likened to "the smoke of the . . locomotive" (Rollins 883).

Whether used as a utilitarian measure of usage or wastefulness, or as a term of explanation or description, however, these references to machine technology, heavy industry, and the industrial city provide a context in which the bodily identity of Old Faithful becomes clearer. Though Muir grouped geophysical eruptions, wind-and-wave hydraulics, and botanical cycles as the percussive "orderly love-beats of Nature's heart," the industrial context produced a different cardiac model. The clockwork regularity of Old Faithful's pulse, when set within the context of an industrializing America, defines the geyser as an industrial-age bodily icon. The eminent physician William Osler wrote that a man must realize "that he is a machine" (William Osler's Collected Papers 5), and the American geophysical expression of that machine body becomes Old Faithful geyser.

Old Faithful in this sense is a synecdoche of the valorized body of the industrial era - a body understood as a machine whose pulse must be regular as clockwork. It is male, in that the realm of heavy industry was gendered masculine (despite the female operatives in textile mills), and its eruptions encompass the ejaculative in the arterial. Indeed, Muir emphasizes that geysers sometimes erupt for periods of nearly one hour, "standing rigid and erect," "seeming so firm and substantial and permanent" (Our National Parks 42, 54).

Such expression of male virility is fully consonant with the new industrial ethos of the later nineteenth century, and Old Faithful thus exemplified the ideals of an industrial society organized for maximal rationalized production. Like the railroads and well-run industrial plants, Old Faithful produced on schedule. True, its eruptions varied by a few minutes, but the concept of hourly regularity was intact, as the numerous tributes to the geyser as reliable, punctual, regular as a clock all indicate. Old Faithful reassuringly enacted the unvarying, relentless rhythms of an industrial system and thus seemed to be the "American incarnation," in Myra Jehlen's terms, of the capitalistic social order of industrial, technological production. Its pulse could be measured by the clock; its very arterial rhythm seemed to be nature's own precocious foreordination of the American modernity manifest in the industrial system.

"Nature's nation" thus was validated by nature's own industrial pulse. The very geophysical heart of America beat the rhythms of mechanization. Those seeing the geyser basin as a version of Pittsburgh or a similar "industrial centre" thus could 
appreciate Old Faithful as the paradigmatic pulse of that very system. Presumably, those responding with approbation also felt their interests well served by the new industrial order. Represented by those who gathered in May 1872 to view Moran's Yellowstone painting, these were, as one railroad executive described them, "the press - the literati- ... the rich people" (qtd. in Kinsey 73).

Evidently, however, the geyser basin of Yellowstone also aroused anxieties pertinent to the industrial system and thereby to its bodily identity. No other geyser approached Old Faithful in regularity of pulse. Its punctuality was offset by other geysers' "capricious[ness]" (Francis 34) and "misbehavior" (Weed, "Geysers" 294), and some of the geyser names suggest the anxiety evoked by their very irregularity and turbulence: Hurricane, Restless, Spasmodic, Spiteful, Impulsive, Fitful, Spasm. Against Old Faithful, the very unpredictability of other geysers needs to be engaged, not solely in geophysical terms but, as with Old Faithful, in those of sociocultural issues in late nineteenth- and early twentieth-century America.

For Yellowstone's old identity as hell-on-earth was not quite effaced or even entirely repressed despite the vigorous efforts of its post- 1870 spokespersons. The continuation of the infernal identity, however, has less to do with an inadequate campaign on behalf of the new Yellowstone "Wonderland" than it does with certain contemporary representations of industrial America. Ironically, just at the point when the cohort of photographers, painters, railroad executives, publishers, et cetera collaborated to identify Yellowstone as America's "Wonderland," public discourse in the US was fashioning an infernal identity for industrial America. While the West was newly configured in edenic terms, the industrial Northeast and Midwest were assigned Yellowstone's old identity as hell-on-earth.

In fact, from the 1860s, fiction writers, journalists, and illustrators presented the new urban industrial order in terms of the infernal. Woodcuts and lithographs, for instance, in Harper's Weekly Magazine (1 Nov. 1873; 7 July 1888) showed tense laborers shoveling coal into beehive coke ovens as flames roil skyward, while other bare-chested workmen tend the fiery furnaces of the iron mill as flames backlight the night sky in a blinding blaze. Writers, too, produced these kinds of infernal images. Rebecca Harding Davis, in Life in the Iron Mills (1861), published in the Atlantic Monthly, described a "city of fires, that burned hot and fiercely in the night. Fire in every horrible form. . . caldrons filled with boiling fire. . . . It was like a street in Hell" (20); "like Dante's Inferno" (27). Industrial Pittsburgh, just 60 miles north 
of Davis's Wheeling, was characterized in 1883 by a travel writer as "the great furnace of Pandemonium ... the outer edge of the infernal regions" (Glazier 332).

Such accounts of industrial, technologically driven America corresponded to the characterization of "American Nervousness," which, in 1881, George Beard attributed to an urbanizing American environment of traction railways, industrial machinery, electrification, steam engines, factories, the very locomotive rods and pistons moving the passenger cars of the Northern Pacific, the Burlington Route, and the Oregon Short Line that brought visitors to Yellowstone as of the 1880s. While Turner affirmed the westward path of civilization as "the steady growth of a complex nervous system," Beard blamed that same civilization for overtaxing the body's neural system in a world thought to engender a host of diseases, including consumption and neurasthenia, whose etiology was found in cities, industrial plants, and fast-paced temporal pressures.

The tourists at Yellowstone came to experience awe at Old Faithful, but evidence indicates that visitors who produced travel texts on their experience at the park did so as inhabitants of an industrial, technological world. This is to say that the texts representative of their experience show a Yellowstone-especially Old Faithful and the geyser basin-framed in experience largely of industrialism and its conditions of production and labor. As Old Faithful became an icon of industrial America, the erratic surrounding geysers, boiling springs, and mud volcanoes were read as a statement on the industrial pulse/body under mortal threat. The geyser area was a rearview-mirror image of the industrializing US.

Muir, the active agent in the production of a Yellowstone "Wonderland," worked to allay anxieties about danger there. Addressing a middle-class reading public, he framed his park description in reassurances that "most of the dangers that haunt the unseasoned citizen are imaginary," that "over-civilized people" are subject to "irrational dread," for instance, of rattlesnakes and murderous Indians ("No scalping Indians will you see" [Our National Parks 51]). "Fear nothing," he says, for "no town park you have been accustomed to saunter in is so free from danger as the Yellowstone" (Our National Parks 57-58). Muir then tries to make the old hellish nicknames sound zany and fun, as though anticipating the later-twentieth-century theme park. Names like "Hell Broth Springs," the "Devil's Caldron," and "Coulter's Hell" are "so exhilarating that they set our pulses dancing" (Our National Parks 58). Muir sets up a sympathetic pulsing of the geothermal and the arterial in the realm of 
rhythmic movement whose beat is emphatically more musical than mechanical. As partners, the visitors and the geysers have a ball.

Others, however, did not reproduce Muir's terpsichorean rhetorical strategy. Travelers' accounts through the 1880 s to the 1910 s continued to enforce a somber linkage between the geyser basin and the inferno. By implication, their descriptions are shadowed by the presumed presence of demonic, monstrous bodies in hell. And their statements show the extent to which industrial-age America did not efface the old Yellowstone identity as "a place where hell bubbles up" but actually renewed it. They described "a seething caldron over a fiery furnace" emitting a "villainous smell" ("Washburn" 434). One of the mud volcanoes bears "testimony to the terrible nature of the convulsion that wrought such destruction" (Langford 354). A writer in Scribner's Magazine noted the "weird, uncanny, sulphurous, and at times even dangerous" aspect of the geyser area (Hague 516). Another said, "It seemed as if we were looking upon a panorama of the Inferno" (King 597), and still another remarked that the air was "burden[ed] . . . with such sulphurous odors that at times it was rendered almost unfit for respiration" (Owen 193). A mother shepherding her seven children through a Yellowstone vacation in 1905 recalled that "like everybody else, we loved Old Faithful . . . feared Excelsior, admired the Giant and Beehive." But, she said, "the horrible rumbling as if an earthquake were imminent and the smell of brimstone made me eager to get my brood into the valley of safety beyond the Yellowstone" (Corthell 1466). Even the scientists reverted to fraught language in description of the geyser: the Excelsior is "a violently boiling cauldron[;] ... its waters may be seen in violent ebullition" (Jagger 324).

Absent Old Faithful, and unable to join in the spirit of $\mathrm{Mu}-$ ir's injunction to "fear nothing" and dance, texts from the 1870 s, including Muir's, link the geyser basin with the inferno in affirming its volcanic geophysics. In 1896, Arnold Hague of the United States Geological Survey asserted that "all geologists who have visited [Yellowstone] concur that the 'great body' of rock and mineral is "volcanic," (Hague, "Age of Igneous Rocks" 447). Two years later, a geologist graphically described the process: "Volcanoes developed throughout the entire Rockies... . Great masses of lava were intruded into the rocks. ... Beds of volcanic ash testify to violent explosive volcanic activity" (Tarr 1407). The novelist Owen Wister's hero, the Virginian, visits the geysers and smells a "volcanaic [sic] whiff" (Sears 169). One writer compared the probable eruptive force of the Yellowstonearea volcanoes with those of the widely publicized recent erup- 
tions of Krakatoa (1883) and of Tarawera, New Zealand (1886) (Weed, "Fossil Forests" 235).

US visitors to Yellowstone were not encouraged to consider the likelihood of renewed volcanic activity. (Muir reassured them that "the fire times had passed away, and the volcanic furnaces were banked" [Our National Parks 64]). The "glass road" of volcanic obsidian over which they rode in wagons and stage coaches to the geysers was considered a wonder, not a threat.

Yet images of the inferno indicate anxieties not allayed by reassurances that the fires were extinct. The spewing, hissing eruptions proved otherwise. An 1897 "Editor's Study" column in Harper's cited a "lady" who considered the geyser area of Yellowstone as "the safety-valve of the United States": The geysers function as "vent-holes of its internal fires and explosive energies, and but for the relief they afford, the whole country might be shaken with earthquakes and be blown up in fragments" (320). The column's author reported it "not encouraging" (320) to feel the hot crust underfoot and identified the subterranean area as "a terrible furnace" (321).

The imagery of safety value and furnace, together with that of the danger, destruction, and chaos of the inferno, also tended to collapse boundaries between Yellowstone and the industrial East and Midwest. Public discourse indicates that apart from the pleasures of Old Faithful, the Yellowstone visitors alighted at the geyser basin only to encounter a geophysical version of the very inferno familiar to them from fictional and journalistic accounts of the material environment of industrial Eastern and upper Midwestern cities of the US.

Just as Old Faithful provided reassurance about the health of the industrial order, so the erratic and frightening geyser basin was read as a geophysical text on sociocultural threats to the new industrial order. There is some evidence that such threat was perceived in bodily terms with reference to industrial workers occupying "t' Devil's place" (Davis 20), workmen who were "bad" and "desperate" enough to be condemned to hell (Davis 27). The heaving, spewing, violent, and capricious geysers and volcanoes replicated an industrializing scene periodically rife with social turmoil, including strikes and riots devolving from conditions of labor and wages. In this sense, the erratic, arrhythmic geysers are a homology of the bodies necessary to keep the industrial world in mechanistic synchrony that instead, at intervals, subvert its clockwork rhythms. Such bodies, swarthy, carbon-blacked, and mud-caked - as Davis termed them, "filthy and ash-covered" (24), "coarse and vulgar" (25) - threaten the clockwork pulse of the industrial order. Like erratic geysers, they 
"pulsate in rhythmic beats from the mighty heart of internal chaos" (Townsend 163). In Life in the Iron Mills they are "boisterous" (Davis 26), but at Yellowstone "infernally angry enough to emit 'sighs, moans, and shrieks'" (Sedgwick 3573).

The sulphurous, heaving mud volcanoes, hissing steam vents, and explosive eruptions - the inferno-had a textual foreground, moreover, in the dire volcanic social vision recurrent in public discourse in the US from the early nineteenth century and deeply engaged with the social body of nonelites. Political, religious, and educational figures had recurrently exploited volcanoes as a terrifying metaphor for the collapse of social order in the US, as Fred Somkin has shown. Back in 1788 Fisher Ames of Massachusetts warned at a political convention that "a democracy is a volcano, which conceals the fiery materials of its own destruction" (qtd. in Somkin 39). In 1817 the Columbian Orator reprinted Yale president Timothy Dwight's description in the "Conquest of Canaan" of "a fiery Judgment Day marked by quaking, fire-belching mountains" (Somkin 39). The possibility that slavery or some other issue might prompt riotous rupture of the social order led Reverend Ephraim Peabody in 1846 to say that while "all may be smooth and fair on the surface," the "fires of a volcano are moving beneath the thin crust, and ... in a moment they may burst through and lay the labors of centuries in ruins" (7). In 1855 the Reverend Richard Storrs voiced his fear that crime, slavery, vice, and Catholicism threatened the US, which he feared slept "on the crater's edge" as "fiery floods threaten an overflow ... more terrible than was felt by Pompeii or Herculaneum" (21). In a Fourth of July oration of 1842, Horace Mann speculated that the nation "is an active volcano of ignorance and guilt" (29).

The eruption of strikes and riots in the later nineteenth and early twentieth centuries also prompted description in volcanic terms. The "political and industrial battles" in Colorado from 1894 to 1904 , for instance, led to the publication of a report from the US Commissioner of Labor (1905): "The reading of that report leaves one with the impression that present-day society rests upon a volcano, which in favorable periods seems very harmless, but, when certain elemental forces clash, it bursts forth in a manner that threatens with destruction civilization itself" (Hunter 303). Statements of this kind produce a volcanic social body correlative with the rumored western hell-on-earth at Yellowstone, and thus the nineteenth-century US becomes a continuum of volcanic geopolitics.

Possibilities for sociocultural "volcanic" explosion apparently intensified with the availability of the new explosives in- 
vented by Alfred B. Nobel in 1866 and developed in the US by the Du Pont Corporation and others. Nobel's work enabled production of a stable explosive in which nitroglycerine was mixed with an inert filler, such as sawdust, then pressed into paper cylinders, and set off with a detonator. Used in construction, mining, and civil engineering, it was lightweight and portable.

And like the explosive volcano, dynamite served to express deep anxieties about hidden dangers of social disorder. Anybody in possession of a stick of dynamite became a potential oneperson volcano. Josiah Strong's best-selling social critique, Our Country: Its Possible Future and Its Present Crisis (1885) described as "social dynamite" the "largely foreign" male population of "roughs[,] ... lawless and desperate men of all sorts" (132). Strong's "social dynamite" gained credence the following year, when some of the eight anarchists found guilty of detonating the bomb that killed a policeman in Chicago's Haymarket riot spoke in the language of explosive social change. August Spies declared, "[F]rom Jove's head once more HAS SPRUNG A MiNERVA-DYNAMITE!" (7). Revolutions, he added, result from certain "causes and conditions," like "earthquakes and cyclones" (8). One may recall the Yellowstone visitor anxious about the earth hot under her feet as Spies's speech warned that laboring wage slaves would rise in revolt: "[E]verywhere, flames will blaze up. It is a subterranean fire. You cannot put it out" (10). Spies's fellow anarchist, Albert P. Parsons, who denied using dynamite to cause the 1886 Haymarket riot, nonetheless declared its efficacy as "a democratic instrument" and was quoted by one alarmed author as citing it as a "splendid opportunity ... for some bold fellow to make the capitalists tremble by blowing up [the Chicago Board of Trade] building and all the thieves and robbers that are there" (McLean 33).

The texts celebrating a clocklike Old Faithful and deploring the infernal adjoining geysers would seem hostile to the notion of dynamiting buildings or otherwise altering the social order with incendiary devices. Such texts were not produced by those laboring 12 hours daily in dangerous, debilitating, low-paying toil, but by those sufficiently affluent to buy rail and coach seats to the Rockies, to stay at hotels or to camp in the Wylie Company's system of tents (beds and meals with campfires at the rate of five dollars per day), to take leave of a primary residence for weeks at a time. These, not the self-described wage-slave laborers with anarchist views, were the visitors poised to applaud Old Faithful.

And these were the visitors who shuddered when, unexpectedly, one or another of the other geysers "burst forth again with- 
out warning, and even greater violence" (Francis 35) who saw eruptions "pulsate in rhythmic beats from the mighty heart of internal chaos." For civil violence had abated but not ceased in the decades following the Civil War, as seen in such events as the deadly Great Railroad Strike of 1877 over the issues of hourly wages, the Haymarket riot of 1886 which started over the eighthour work day, the New Orleans race riots of 1866, the Homestead Strike of 1892, the Pullman Strike of 1894, the miners' strike at Coeur d'Alene, Idaho, in 1899, the above-mentioned Colorado strikes and riots from 1894 to 1904 -all of which seemed to nativists dangerously explosive. Add to these the actual explosives, from the bomb thrown into Chicago's Haymarket to the carload of dynamite detonated by striking miners to blow up the mine concentrator, an area where wastes were extracted from ores, at the Coeur d'Alene mine.

It is important to recognize that Yellowstone's visitorscamped with their own "wagons, tents, and provisions," their "coffee pot, frying pan and kettle," and "a buffalo robe to spread on a pile of fir, pine, or hemlock twigs, with blankets for covering, [which] makes a bed which renders that city pest, insomnia, an impossibility" (Logan 160)-looked to Old Faithful to help them keep faith in an industrializing nation that was built, some feared, on incendiary volcanic soil. Given their class position, the American body politic and the mechanistic body of the new industrial order must have seemed tenuous, contingent, and contested. In the post-1870s decades it was not clear whether the America of Old Faithful would become an industrial-age "Wonderland" or manifest its longterm national, geopolitical identity as "a place where hell bubbles up."

\section{Works Cited}

Armstrong, Katherine. "Work Indoors and Out: The Flowers of Yellowstone Park." Independent May 1898: 562.

Barwell, Richard. On Aneurism: Especially of the Thorax and Root of the Neck. London, 1880.

Beard, George. American Nervousness. 1881. New York: Arno, 1972.
Burroughs, John. Camping and Tramping with Roosevelt. Boston: Houghton, 1907.

Clendening, Logan, ed. Source Book of Medical History. 1942. New York: Dover, 1960.

Comstock, Theodore B. "Engineering Relations of the Yellowstone Park." American Journal of Science Nov.Dec. 1878: 460-61. 
Corthell, N. E. "A Family Trek to the Yellowstone." Independent June 1905: 1460-67.

Dale, Stephen M. "Through Yellowstone on a Coach." Ladies' Home Journal Aug. 1904: 5-6.

Davis, Rebecca Harding. Life in the Iron Mills: Or, The Korl Woman. Old Westbury: Feminist, 1972.

"Editor's Study." Harper's New Monthly Magazine Jan. 1897: 320-25.

Emerson, Ralph Waldo. "The American Scholar." Selections from Ralph Waldo Emerson: An Organic Anthology. Ed. Stephen E. Whicher. Cambridge: Riverside-Houghton, 1957. 63-80.

Natural History of Intellect. 1893. Boston: Houghton, 1904.

Society and Solitude. 1870. Vol. 7 of The Complete Works of Ralph Waldo Emerson. Boston: Houghton, 1904. 12 vols. 1903-21.

Francis, Fr. "The Yellowstone Geysers." Littell's Living Age 8 Apr. 1882: 31-36.

Glazier, Willard. Peculiarities of American Cities. Philadelphia, 1883.

Hague, Arnold. "Age of Igneous Rocks of the Yellowstone." American Journal of Science June 1896: 445-56.

- "The Yellowstone National Park." Scribner's Magazine May 1904: 513-27.

Hales, Peter B. William Henry Jackson and the Transformation of the American Landscape. Philadelphia: Temple UP, 1988.

Hayden, F. W. "The Hot Springs and Geysers of the Yellowstone and Fire- hole Rivers." American Journal of Science and the Arts March 1872: 161-76.

- "The Yellowstone National Park." American Journal of Science and the Arts April 1872: 294-97.

Henderson, C. Hanford. "Through the Yellowstone on Foot." Outing May 1899: 161-67.

Hunter, Robert. Violence and the Labor Movement. New York: Macmillan, 1922.

Jagger, T. A. "Some Conditions Affecting Geyser Eruption." American Journal of Science May 1898: 323-33.

Jehlen, Myra. American Incarnation: The Individual, the Nation, and the Continent. Cambridge: Harvard UP, 1986.

King, Frank B. "In Nature's Laboratory: Driving and Fishing in Yellowstone Park." Overland Monthly June 1897: 594-603.

Kinsey, Joni Louise. Thomas Moran and the Surveying of the American West. New Directions in American Art. Washington: Smithsonian Institution, 1992.

Koch, J. "Discovery of the Yellowstone National Park." Magazine of American History June 1884: 497-512.

Kolodny, Annette. The Lay of the Land: Metaphor as Experience and History in American Life and Letters. Chapel Hill: U of North Carolina P, 1975.

Langford, Nathaniel P. "The FolsomCook Exploration of the Upper Yellowstone in the Year 1869." Contributions to the Historical Society of Montana. 5 (1904): 349-69. 
Lawson-Peebles, Robert. Landscape and Written Expression in Revolutionary America. New York: Cambridge UP, 1988.

Le Conte, Joseph. "Geysers and How They Are Explained." Popular Science Monthly Feb. 1878: 407-17.

Logan, Mrs. John A. The Home Manual: Everybody's Guide in Social, Domestic, and Business Life. Chicago: H. J. Smith, 1889.

Mackenzie, James. The Study of the Pulse, Arterial, Venous, and Hepatic, and of the Movements of the Heart. New York: Macmillan, 1902.

Mann, Horace. An Oration, Delivered before the Authorities of the City of Boston, July 4, 1842. Boston, 1842.

McKinsey, Elizabeth. Niagara Falls. Icon of the American Sublime. New York: Cambridge UP, 1985.

McLean, George N. The Rise and Fall of Anarchy in America. . . Chicago, 1888.

Mitchell, S. Weir. "Through the Yellowstone Park to Fort Custer." Lippincott's Magazine of Popular Literature and Science June 1889: 688-704.

Muir, John. Our National Parks. 1901. Madison: U of Wisconsin P, 1981.

"The Wild Parks and Forest Reservations of the West." Atlantic Monthly Jan. 1898: 15-28.

Osler, William. The Principles and Practice of Medicine. . . 2nd ed. New York, 1895.

William Osler's Collected Papers on the Cardiovascular System. Ed. W. Bruce Fye. Birmingham: Classics of Cardiology Library, 1985.
Owen, W. O. "The First Bicycle Tour of the Yellowstone National Park." Outing June 1891: 191-95.

Peabody, Ephraim. A Sermon Delivered before the Boston Fraternity of Churches, April 2, 1846. Boston, 1846.

Rollins, Alice Wellington. "The Three Tetons." Harper's New Monthly Magazine May 1887: 869-90.

Schmeckebier, L. F. "Our National Parks.” National Geographic Magazine June 1912: 531-39.

Sears, John F. Sacred Places: American Tourist Attractions in the Nineteenth Century. New York: Oxford UP, 1989.

Sedgwick, Henry D. "On Horseback Through the Yellowstone." The World's Work June 1903: 3569-76.

Seltzer, Mark. Bodies and Machines. New York: Routledge, 1992.

Somkin, Fred. Unquiet Eagle: Memory and Desire in the Idea of American Freedom, 1815-1860. Ithaca: Cornell UP, 1967.

Spies, August. "Address of August Spies." The Accused, The Accusers: The Famous Speeches of the Eight Chicago Anarchists in Court. New York: Arno, 1969. 1-23.

Storrs, Richard. Home Missions: As Connected with Christ's Dominion. . . . New York, 1855.

Strong, Josiah. Our Country: Its Possible Future and Its Present Crisis. New York, 1885.

Tarr, Ralph S. "Geology of the Yellowstone Park." Independent 17 Nov. 1898: 1406-1408; 1 Dec. 1898: 15721576. 
Thoreau, Henry David. Cape Cod. A Week on the Concord and Merrimack Rivers .. Cape Cod. New York: Library of America, 1985. 847-1039.

Townsend, Mary Trowbridge. "A Woman's Trout-Fishing in Yellowstone Park." Outing May 1897: 163-65.

Trachtenberg, Alan. Reading American Photographs: Images as History, Mathew Brady to Walker Evans. New York: Hill, 1989.

Turner, Frederick Jackson. The Significance of the Frontier. 1893. Reprinted in The Frontier in American History. New York: Dover. 1-38.
Twain, Mark. Life on the Mississippi. 1883. Reprint. New York: Penguin, 1984.

"The Washburn Yellowstone Expedition, Nos. 1 and 2." Overland Monthly May 1871: 431-37; June 1871: 489-96.

Weed, Walter. "Fossil Forests of the Yellowstone." School of Mines Quarterly 13.3 (1892): 230-36.

- "Geysers." School of Mines Quarterly 11.4 (1890): 289-306.

"Yellowstone Park as a Summer Resort." Nation 27 Sept. 1900: 248-50. 